\title{
Guerra de palavras: liberais e servis frente às tropas napoleônicas
}

Bruno Sobrinho e

Lucas Soares Chnaiderman

\section{Resumo:}

A invasão da Espanha por tropas francesas, durante o período napoleônico, foi um dos episódios mais importantes para a história do império espanhol. A tentativa deste artigo é ilustrar, não a guerra no sentido bélico da palavra, existente entre franceses e espanhóis, mas o enfrentamento protagonizado por dois grupos que se expressavam na política hispânica daquele período: os liberais e os servis. Os primeiros encabeçaram um movimento reformista/ revolucionário que visava modernizar e construir novas instituições políticas para o império. O outro grupo era mantenedor da ordem instaurada e, em alguns pontos, opositor direto das mudanças propostas nesse momento. Utilizando-se de periódicos, este artigo se propõe a apresentar ao leitor uma breve visão desse embate que caracterizou a modernidade hispânica e iniciou o século XIX daquele país.

Palavras-chave: liberalismo espanhol - opinião pública - Guerra de Independência Hispânica 
Os fatos decorrentes da decisão tomada por Napoleão Bonaparte em I807 são muito conhecidos. O imperador dos franceses efetivou a ocupação da península ibérica e, assim, implementou a estratégia pensada contra os britânicos desde finais do século XVIII. Inicialmente, buscou o apoio do rei espanhol, Carlos IV, para a anexação e partilha de Portugal e seus domínios. Assim, visava a efetivação do Bloqueio Continental e o isolamento da Inglaterra. Obteve, então, a assinatura do Tratado de Fontainebleau em 27 de outubro. A medida acelerou a crise na Espanha, pois motivou a reação de Fernando, filho e herdeiro de Carlos IV que, em nome da oposição aos afrancesados e contando com o apoio inglês, liderou um motim em Madri e tornou-se o novo rei espanhol: Fernando VII, que governou até fevereiro de I808. Nesse momento, Napoleão chamou pai e filho à Baiona e ambos foram forçados a renunciar ao trono espanhol em favor de José Bonaparte, irmão do Imperador. Iniciava-se, assim, um longo período de guerra e resistência, que marcaria o destino da monarquia espanhola dentro e fora da Europa. Os exércitos napoleônicos avançaram sobre um território ocupado por espanhóis que, em armas, clamavam pela legitimidade do rei deposto.

No entanto, apesar da importância desses fatos, não buscaremos ilustrar neste texto os acontecimentos de uma guerra no sentido bélico. É certo que a Guerra de Independência recebe esse nome por ser um conflito protagonizado por espanhóis resistentes às invasões napoleônicas, mas a guerra e suas circunstâncias nos servem apenas como pano de fundo para explicar um enfrentamento que ultrapassou os marcos da presença francesa. Houve, na Espanha, muito mais do que uma invasão; houve uma guerra que, além da oposição ao exército de Napoleão Bonaparte, possibilitou a contestação, e também a defesa, dos valores do Antigo Regime, no interior de uma crise sem precedentes na monarquia hispânica. ${ }^{I}$ Panfletos e periódicos circularam livremente pela primeira vez na Espanha desintegrada pelas invasões e manifestaram uma

I No início do século XVIII, a Espanha havia passado por uma crise dinástica também de grandes proporções, com exércitos estrangeiros batalhando em seu território; porém as consequências da guerra de sucessão entre I700 e I7I4 não foram tão graves e duradouras como a revolução de I808. A tradição historiográfica de chamar os eventos da virada do século XIX de "revolução" já é um indicativo deste fato, como na afirmação de Miguel Artola (2008, p. 67): "en la crisis de 1808 el primer hecho destacable es la quiebra total de las personas e instituciones representativas del Antiguo Régimen". Ainda que muitas das conclusões de Artola tenham sido matizadas, é comum a denominação de crise sem precedentes para o período descrito neste texto. Uma boa descrição da situação é dada por Roberto Breña (2006, p. 73): "La ausencia del monarca legítimo, la imposición de un rey extranjero, la sublevación popular contra Napoleón y la guerra que siguió a ésta llevaron a los españoles a plantearse como nunca antes una serie de cuestiones políticas cruciales, de cuya solución práctica dependían en buena medida la expulsión del ejército invasory, más tarde, la recuperación del país”. 
outra guerra dentro da guerra de independência: uma guerra de palavras que opunha os autodenominados "liberais" e "servis" e que invadia o espaço já compreendido como público: dezoito juntas de governo espalhavam-se pela Espanha desde I808 e se autoproclamavam soberanas, ${ }^{3}$ Cortes Constituintes instalaram-se na cidade de Cádis a partir de I8IO e periódicos registravam a diversidade de opiniões que acompanhava o processo de desintegração das velhas estruturas de governo.

Essa situação particular colocava em questão todas as antigas elaborações acerca da soberania da monarquia espanhola. Explicando melhor: a ausência do monarca e a fragmentação das estruturas criadas pelo Antigo Regime impuseram a necessidade de buscar argumentos para garantir a soberania espanhola face ao invasor francês e, paralelamente, justificar a soberania real de um rei ausente. A situação era nova e complexa, mas a novidade que queremos ressaltar é que, pela primeira vez na Espanha, as diversas concepções políticas foram discutidas para além do espaço privado, formando uma única esfera pública ${ }^{4}$ e a ideia de que a política se movia pelo que chamavam de "Rainha do Mundo": a opinião pública. ${ }^{5}$

A ausência das antigas autoridades e instituições convergiu no desaparecimento prático da censura. E aqui iniciamos o primeiro momento de nossa análise. Mais do que a guerra propriamente dita, a ausência de censura e a

2 Essa divisão ainda é utilizado por alguns historiadores, como em SÁIZ; SEOANE, I983. Em compensação, outros autores, como Ramón Solís (I987), preferem não fazer divisões, alegando que apenas os radicais estavam sempre em um grupo, enquanto a maioria não tinha linha ideológica muito fixa. 3 BREÑA, 2006, p. 84-85: "Es verdad que la iniciativa para la formación de las juntas partió, como era de esperarse, de las autoridades establecidas y de personas con cierta posición social, pero pocos hubieran podido hacer estas juntas si el pueblo no las hubiera apoyado". Miguel Artola, por sua vez, defende que as juntas foram uma revolução, comparada às assembleias populares tomadas pelo povo da França jacobina; já Jean-René Aymes, pelo contrário, toma as juntas como o fator de estabilidade do regime, tendo sido o que impediu o povo de realmente assumir o poder (AYMES, I990).

4 Jürgen Habermas dedicou um de seus livros a fazer uma análise da nova esfera pública, embora visasse outros países que não a Espanha, em Mudança estrutural da esfera pública, investigação quanto a uma categoria da sociedade burguesa (Rio de Janeiro: Tempo Brasileiro, 2003). Segundo o autor, a esfera pública moderna, com indivíduos discutindo quaisquer temas, com destaque para a política, é uma re-significação da esfera pública literária típica do Antigo Regime. Uma referência obrigatória para este tema com relação ao mundo hispânico é François-Xavier Guerra (I992, p. I3), que escreve:

"Lo radicalmente nuevo [na revolução espanhola] es la creación de una escena pública cuando este nuevo sistema de referencias deja los círculos privados en los que hasta entonces había estado recluido, para irrumpir en plena luz". Ou seja, a esfera pública é mais do que o ambiente no qual se deslocam os novos atores políticos, ela própria é a novidade revolucionária.

5 BARROS; MOREL, 2003. Embora este livro seja sobre a época da independência e império no Brasil e a imprensa, algumas de suas conclusões são de caráter mais geral, como a que reproduzimos neste artigo. 
discussão do mundo político na esfera pública permitiram a publicação de periódicos que, entre si, disputavam nas definições de novos paradigmas a implementação de projetos que pudessem solucionar a crise presente e adiantar planos para o futuro da Espanha. Todos os panfletos podiam ser impressos, várias ideias podiam ser debatidas. ${ }^{6}$

A partir de I8Io surgiu um fato novo. As Cortes - convocadas na forma de uma assembleia nacional moderna, onde os deputados representavam não mais estamentos ou localidades, mas sim a nação soberana ${ }^{7}$-, situadas na cidade de Cádis, reuniram-se em 24 de setembro e a discussão na esfera pública ganhou um novo centro: os assuntos parlamentares. As Cortes eram a derradeira tentativa de efetivar um governo central para a monarquia, concretizando uma reunião de deputados que buscava superar a hierarquia do Antigo Regime e incluía a América. ${ }^{8}$

Uma das primeiras medidas tomadas foi a decretação da liberdade de imprensa ainda em novembro de I8IO. ${ }^{9}$ Essa declaração formal impulsionou a

6 Apesar de toda essa inédita liberdade, alguns temas ainda permaneciam "sagrados". Um exemplo foram os temas religiosos. Eles sempre foram censurados, o que já foi usado por diversos autores para destacar o pouco liberal e o muito tradicional que foi a revolução espanhola de I808, principalmente pensando na revolução francesa e na tolerância inglesa. Apesar disso, a papel da nova imprensa como divulgadora dos ideais da modernidade e como espaço privilegiado para discussão é inegável (GUERRA, I992, p. 276). Os estudos sobre a imprensa nesse período têm se tornado cada vez mais comum, dentro de um novo marco teórico, como explicam Fuentes e Sabastián: "[a imprensa está situada em] un marco interpretativo más amplio y complejo como es el de la historia de los movimientos políticos, sociales e ideológicos, en cuyo desarrollo los medios de comunicación han actuado muy a menudo como vehículo y, no pocas veces incluso, como protagonistas o factores desencadenantes" (FERNÁNDEZ SEBASTIÁN; FRANCISCO FUENTES, I998, p. IO).

7 As Cortes de Cádis vem sendo objeto constante de estudos, não só devido a um ressurgimento da história política, mas também devido ao bicentenário completado em 2010 (as comemorações chegaram até o Brasil com o colóquio internacional "A experiência constitucional de Cádis"). Para uma maior abordagem sobre o assunto, vide SUÁREZ, I982; e ARTOLA, 2003. O grande ato das Cortes, para além de ampliar o espaço público até a esfera parlamentar, foi a promulgação da constituição, em I8I2, descrita por Jaime Rodríguez (2006, p. 9I): "A constituição de I8I2 aboliu instituições senhoriais, tributo indígena, trabalhos forçados como a mita na América do Sul e os serviços pessoais na Espanha; acabou com a inquisição; e estabeleceu um controle firme sobre a Igreja. Liberdade de imprensa, embora já um fato, foi formalmente proclamada. A constituição da monarquia espanhola, promulgada em março de I8I2, continha estas e outras reformas. A nova carta criou um Estado unitário, com leis iguais para todas as partes do mundo hispânico. Ela substancialmente restringiu o rei e confiou às Cortes um poder decisivo".

8 A representação nacional na forma de uma reunião de deputados era uma proposta diretamente liberal. Nesse sentido, podemos dizer que foi esse um momento de vitória desse grupo, uma vez que os servis propunham a representação nacional de outra forma.

9 O decreto de liberdade de imprensa era razoavelmente amplo. Ele permitia a todos que quisessem imprimir esse direito, extinguindo a censura prévia. Todavia, o mesmo decreto estipulava limites à liberdade de imprensa, como falar de religião e atacar as leis fundamentais da Espanha. Para fazer valer 
criação de muitos outros periódicos, que registram a oposição daquilo que Pierre Vilar denominou "duas Espanhas naturais e paradoxais" (VILAR, I982) que se encontravam e se enfrentavam nas Cortes e disputavam a opinião pública, mas que, entre I8IO e I8I4, ainda estavam unidas contra Napoleão Bonaparte.

Esses dois grupos se autodenominavam servis e liberais. Pretendemos mostrar aqui algumas ideias centrais divulgadas pelos dois mais importantes adversários nessa guerra de palavras: o "liberal" mais antigo e mais lido, o Semanário Patriótico, ${ }^{\text {IO }}$ publicado desde setembro de I808 sob a direção do ilustrado Manuel Quintana, e o "servil" El Censor General, o mais servil dos servis, de acordo com Maria Gruz Seoane, dirigido pelo Marquês de Panés. I

O Semanário Patriótico explicou os termos da guerra: "Não só Napoleão e seus vis satélites tentam entronizar o despotismo a sangue e fogo afrontando os direitos do homem e acabando com toda a espécie de cultura. Também entre nós se levantou uma numerosa seita de prevaricadores políticos que, honrando-se com o nobre título de patriotas, tratam de preparar a submissão da pátria. Como são ignorantes na arte de escrever, tardaram a manejar a pluma, até que um deles ousou publicar um panfleto e, desde então, formam- se partidos de bárbaros que causam danos à república literária. Lutam contra os defensores da constituição e da liberdade e dela tomam os últimos a nossa denominação de liberal e, em contraposição, apelidamos aqueles selvagens de servis, porque eles travam um combate pela servidão. O exército de liberais se distingue mais por sua excelente tática e disciplina do que pelo número de combatentes." 12

A guerra de palavras serviu para a definição dos grupos em luta, mas registra a mutação conceitual implícita nesse campo de batalha. A palavra "liberalismo" apareceu pela primeira vez nas páginas do El Censor General. $\mathrm{O}$ marquês de Panés respondia a um amigo inglês que indagava sobre a terminologia usada no Semanário Patriótico. Dizia ele que o grupo de Quintana se autointitulava liberal e ele perguntava: "que espécie de pássaros são eles que se dizem em guerra contra os servis? Porque na Inglaterra, país da li-

a censura posterior, haveria uma junta de censura, com potência para fazer valer a lei nas punições aos editores e aos autores.

Io SÁIZ; SEOANE, I983, p. 30. Esse número, indicado por um dos redatores do jornal em I809, Blanco White, ainda não é absoluto, pois os hábitos de leitura eram muito parecidos com aqueles do Antigo Regime: leituras públicas e os jornais circulavam de mão em mão.

II Ibidem.

I2 Semanário Patriótico, 29 ago. I8II. Disponível em: 〈http://hemerotecadigital.bne.es/titulos.htm〉, assim como todos os outros números citados. Tradução própria. 
berdade, jamais se conheceu o título de liberal." O Marquês respondia que "os liberais ou libertinos, que é o mesmo, são uns sansculottes, imitadores de Paris", leitores de Montesquieu, Rousseau e da Enciclopédia, "não são liberais e nem pensam sê-lo, e os que se mostram como chefes da escola do liberalismo, já rezaram missa a José [Bonaparte]". Continuava, então: "este é o motivo dessa guerra dos liberais, ou supostos filósofos, contra aqueles que eles chamam de servis, porque são servos da razão ilustrada pela fé, da justiça, da ordem e de nossas sábias leis". ${ }^{13}$

Javier Fernández Sebastián e Juan Francisco Fuentes já registraram a mutação inscrita neste uso da palavra em seu Dicionário político e social do século XIX espanhol. Apontam que os termos "liberal" e "liberalismo" possuem valores semânticos que vão se transformando justamente nesse momento. Como foi dito, "liberalismo" apareceu pela primeira vez nesse confronto, e "liberal", de acordo com os autores, não tinha, antes disso, qualquer sentido político e era usado apenas como sinônimo de "generoso, desprendido". A utilização dos termos nessa citada guerra de palavras inicia a mutação que implica em uma carga semântica com os diversos significados que hoje associamos ao conceito "liberalismo" (FERNÁNDEZ SEBASTIÁN; FRANGISCO FUENTES, 2002, p. 413-428).

Assim, buscamos aqui destacar alguns pontos fundamentais deste confronto que serviu de base inicial para essa definição.

\section{A guerra e a revolução}

A primeira diferença aparece na interpretação da guerra contra os franceses. O Semanário Patriótico se refere ao processo vivido na Espanha entre I808 e I8I4 como "nuestra revolución". i4 A guerra é mais do que a obrigação de lutar pela pátria e expulsar os franceses, é "a melhor e mais oportuna ocasião de assegurar para sempre a nossa felicidade e a de nossos descendentes", ${ }^{15}$ é uma guerra para acabar com o despotismo, verdadeiro motivo da atual situação da nação espanhola.

I3 El Censor General, I5 set. I8II. Disponível em: 〈http://hemerotecadigital.bne.es/titulos.htm>, assim como todos os outros números citados. Tradução própria.

I4 A palavra revolución aparece desde o primeiro número do Semanário Patriótico, em OI de setembro de I808, já com um sentido positivo. Isso se acentua cada vez mais ao longo de sua publicação, tendo a palavra "revolução" um sentido temporal moderno, como aponta Reinhart Koselleck (2006).

I5 Semanário Patriótico, 02 maio I8II. 
Nessa interpretação sobre o que ocorre na Espanha, o Semanário trata de recapitular cada episódio do confronto desde a sua primeira edição e, neste relato, o povo espanhol ganha o papel de protagonista: "O caráter específico que apresenta a nossa revolução desde seu início [...] Quem pode se vangloriar de ser o autor, diretor, desta insurreição sublime, desta resistência heroica que espanta a Europa e desconcerta o tirano? Insensato seria a nossos olhos e aos da posteridade quem aspirasse a esse desempenho exclusivo, que não sendo de ninguém particularmente, é de todos em comum. O povo espanhol é quem resiste." ${ }^{6} \mathrm{O}$ povo é identificado com a nação, a qual está acima de qualquer autoridade: "A nossa revolução não foi feita pelos conselhos, não a fizeram as autoridades constituídas, porém a nação". ${ }^{17}$

A visão dos servis sobre a guerra era mais imediata. Para esse grupo, primeiro era necessário expulsar o inimigo em comum, os franceses, e depois propor qualquer mudança. Esse posicionamento, inclusive, fazia parte do ataque do grupo servil contra os liberais. Dessa forma, no discurso servil, a guerra também era utilizada para diminuir o impacto que pudessem ter as ideias liberais. Assim, está escrito no jornal: "Que remédio pode haver para que não se percam por essa rancorosa divisão uns e outros, e não percam todos? Aqui está a minha proposição de mediador: faça-se um armistício durante a guerra e reúnam-se todos os discursos contra o inimigo comum." Atacando os liberais no mesmo periódico, segue a justificativa para, devido a situação de guerra, negar as reformas que ocorriam na época: "Mas caso percamos essa conjuntura (dirão eles [os liberais]), quando teremos outra? Vem aqui demônio (respondo eu) e se perde a pátria, para o que falta tão pouco, onde diabos hão de estabelecer estas constituições tão luminosas?"I8

\section{Os princípios básicos da Constituição}

A Constituição esteve na ordem do dia desde o afastamento dos reis espanhóis e a entrada do exército francês. No entanto, entre I808 e I8Io, não havia acordo sobre o que se pretendia constituir e qual a forma mais adequada. ${ }^{19} \mathrm{O}$ Semanário Patriótico sempre defendeu a necessidade da reunião de Cortes

I6 Idem, 22 nov. I8Io.

I7 Idem, I8 abr. I8II.

I8 El Censor General, I9 set. I8II.

19 No entanto, havia acima de tudo uma ideia da necessidade de mudança, o reconhecimento de um erro. Como diz Jaime Rodríguez: "Os eventos dramáticos de I808 e I809 transformaram a cultura po- 
Constituintes para o estabelecimento de uma nova e moderna Constituição que pudesse fundar ${ }^{20}$ a nação espanhola. A luta do povo contra o despotismo tinha um fim: estabelecer uma Constituição que pudesse livrar a nação dos males que a afligia até esse momento

Suas propostas foram contempladas com a convocação das Cortes para Cádis em I8IO. No entanto, essa não era a única forma de entender a Constituição espanhola. Alguns acreditavam que já existia uma Constituição da Espanha, pré-figurada nas diversas províncias (Aragão, Astúrias, Castela, etc.), e que, portanto, caberia às Cortes retomá-las e reformá-las para a aplicação em toda a Espanha.

O Semanário Patriótico rebatia essa ideia: "[comentando o discurso de um deputado que defendeu a constituição histórica, dizia] Não sabemos onde está essa Constituição, nem acreditamos que o senhor Cañedo [o deputado] a tenha visto. Se a tivéssemos, bastaria seguramente corrigi-la e melhorá-la; porém há que fazê-la de novo, porque de outro modo voltaríamos a ser o joguete da tirania. Sem boas leis fundamentais não há Constituição, é isto o que nos falta." ${ }^{21}$

Paralelamente, os servis apoiavam-se na necessidade de recuperar uma possível Constituição histórica. As publicações do El Censor General mostram a defesa das leis primordiais que teriam já constituído uma nação hispânica, e essas leis, historicamente estabelecidas, deveriam ser reformuladas nesse novo contexto. "Assim se chamam os primeiros cimentos de uma dada sociedade. [...] Se infere de tudo: que lei fundamental deveremos chamar apenas aquela que, colocada como cimento, sustente uma constituição especial, fazendo com que se distinga de outras, as quais faltando a sociedade constituída deixe também de ser o que foi. Tais são em Espanha: RELIGIÃO GATÓLICA E GOVERNO POR UM REI”. ${ }^{22}$

Para o jornal, tratava-se de lutar por uma reconstrução baseada na tradição espanhola. Só os valores tradicionais poderiam refazer a união da Espanha. Esses valores eram claramente expostos: a religião e a monarquia. Em outras palavras, não havia necessidade de criar novos princípios, eles já existiam historicamente. Havia a necessidade de manter unida a Espanha contra o inimigo comum - a França e o pensamento "jacobino" - e defender os valores tradicionais.

lítica do mundo hispânico. Como Virginia Gueda notou, a crise de I808 da monarquia foi fundamentalmente uma crise política que iniciou um processo de politização que se intensificou rapidamente" (RODRÍGUEZ, 2006, p. 73. Tradução própria).

20 Há um grande debate entre os liberais sobre os termos de fundar a nação ou regenerá-la, restaurá-

-la. Esse debate entre os liberais historicistas e aqueles mais ligados ao futuro, reflete-se também no Semanário, que apresenta argumentos para os dois lados, porém acaba por se definir em uma posição valorizadora do devir. A nação e a pátria estão no futuro, como mostraremos no texto.

21 Semanário Patriótico, 27 dez. I8Io.

22 El Censor General, o4 set. I8II. 
A acusação do El Censor sobre o Semanário, chamando-o de jacobino, parece ser uma constante no debate político. O Semanário Patriótico se defende várias vezes dessa pecha. Em um de seus números, diz que nem toda revolução é jacobina e proclama como seu ascendente histórico os comuneros espanhóis do século XVI:

Todas as revoluções políticas que nos oferecem a história tiveram um caráter tão feroz e sanguinário [referindo-se à Revolução Francesa]? Todas elas acabaram em uma horrorosa anarquia? Em todas dissolveram-se os vínculos sociais, perverteu-se a moral pública e se fez alarde de desumanidade? Chamaremos jacobinos aos holandeses do século XVI porque sacudiram o jugo de um tirano, aos ingleses que chamaram a Guilherme III para que os governassem sob uma sábia constituição, e aos valorosos espanhóis que quiseram nos abrir o caminhos da felicidade lançando-se contra a tirania de Carlos V? Não há dúvida, esses comuneros tão desacreditados em nossas histórias por terem sido mal-sucedidos, pensavam uma reforma geral e não conseguiram porque os interesses da nobreza estavam em contradição com os interesses do povo. ${ }^{23}$

\section{Soberania nacional}

Para os autores do Semanário Patriótico, a constituição deveria ser baseada em um princípio fundamental: a soberania reside essencialmente na nação. Esse era um dos pontos mais revolucionários e sempre defendido pelo jornal desde I808, e isto significava a submissão do rei distante a uma soberania expressa pela reunião de deputados. O grupo de Quintana acreditava que, apesar das antigas referências à origem nacional do poder monárquico, esta soberania havia sido "usurpada" pelo rei: "O rei é o primeiro cidadão de uma nação: pergunto agora: perderá esta por levar adiante os atos de um rei? Ponha-se de um lado o rei, do outro 25 milhões de almas, e que se decida a qual se deve inclinar a balança. Digo mais, se fosse necessário que o rei perecesse, que pereça para salvar a nação, que tomou o partido de perecer por ele”. De acordo com os redatores do periódico, apenas a nação poderia legitimar a autoridade de um rei e, portanto, ela também poderia tirá-la.

Já o periódico servil não via qualquer "usurpação" em tempos remotos ou no presente. Pelo contrário, historicamente o rei havia ocupado um lugar:

23 Semanário Patriótico, 02 maio I8II. 
O Rei era eletivo pelos prelados, grandes e povo, quando nossa sociedade se constituiu. Por outra parte, não tendo sido fundamento para constituí-la a sucessão hereditária, pôde e sobreviveu de fato sem ela, e embora foi reconhecida depois pelo voto comum entre os Pactos e obrigações do povo, ficou desde então colocada entre as constitucionais, sem poder passar a ser mais. ${ }^{24}$

Esse lugar, destinado ao rei pela própria tradição espanhola, era, na verdade, a verdadeira lei fundamental da Espanha.

Entramos num ponto chave da discussão. O que era a nação para os autores destes dois jornais?

O Semanário é enfático: a nação é o povo e é sempre soberana. Daí que o Semanário possa afirmar que a Espanha só se constitui verdadeiramente como nação quando se reúne em Cortes, pois então está representada e é soberana: "Desde o 24 de setembro de I8Io [reunião das Cortes] formam [os espanhóis] uma verdadeira associação política e são realmente uma nação, um povo". ${ }^{25}$

Já os servis não admitiam a ideia de que a nação estava em formação. Para eles, a nação, no seu sentido antigo e estamental do Antigo Regime, já existia. Foi esse um dos pontos de fundamental discordância entre os autores dos dois jornais. A proposta inicial do jornal servil El Censor é tornar "recta la opinión pública". ${ }^{26} \mathrm{E}$ por esse princípio, ele se julgava capaz de analisar outros periódicos e, assim, acusá-los ou não de escrever coisas absurdas - esta era a ideia contida no título: censor geral. Assim, ele expressa claramente sua "censura" à ideia de soberania nacional quando se refere ao Semanário Patriótico:

O que se insere desde a página I62 [analisando o Semanário Patriótico] [...] [A soberania reside essencialmente na nação e pode mudar suas leis fundamentais sem apoio do rei]. Isto não tem fundamento nem nas decisões das Cortes Antigas nem nas opiniões dos homens mais sábios. O Semanarista diz que o rei está contido na nação. Logo esta nação é corpo sem cabeça. ${ }^{27}$

Ou seja, a nação, no campo semântico servil, possuía o valor tradicional e, portanto, se via como um corpo social. Cada pueblo teria um lugar na sociedade

24 El Censor General, o4 set. I8II.

25 Semanário Patriótico, 22 nov. I8Io.

26 Ideia defendida logo em seu prospecto.

27 El Censor General, 29 set. I8II. 
e essa proposta estaria vinculada diretamente ao formato de uma sociedade dividida por estamentos:

O povo, isto é, o comum dos espanhóis, deseja que cada indivíduo particular tenha e guarde um lugar fixo na sociedade. Essa se concebe constituída quando todos os que a compõem dependem mutuamente, sustentam-se sem exceder os limites do lugar que ocupam. Assim, como em uma abóbada em que as pedras se ajudam entre si e dão solidez à obra por estarem unidas, porém ao faltar uma ou outra o edifício fraqueja e ameaça cair, a sociedade é do mesmo modo. ${ }^{28}$

Para os autores do Semanário, a nação era formada pelo conjunto de cidadãos e, embora soberana, não podia exercer a soberania por si mesma, e por isso precisava ser representada. A defesa da representação nacional feita no Semanário Patriótico constituiu um dos pontos definidores dos princípios expressos pelo periódico e foi reforçada a todo instante. Os autores que escreviam o Semanário Patriótico poderiam discordar das decisões aprovadas pelas Cortes reunidas em Cádis, mas jamais questionavam a legitimidade das decisões tomadas pela maioria dos deputados.

A defesa da representação de uma nação "una e indivisível" combatia dois inimigos: a divisão por estamentos e a divisão de força entre as províncias, agora expressa na formação das dezoito juntas soberanas. As antigas Cortes espanholas eram divididas entre os "três estados" e muitos espanhóis ainda defendiam essa forma de representação. Todavia, os deputados liberais presentes nas Cortes lutavam pela indivisibilidade. As fortes palavras do Semanário traduzem bem esse sentimento: "Os deputados reunidos em Cortes não são deputados de suas classes ou profissões respectivas, mas de todo o conjunto de cidadãos a quem se dá o nome de Povo”. ${ }^{29}$

Paralelamente, a luta contra a divisão expressa na organização das províncias ocupa muito mais espaço nas páginas do Semanário Patriótico. A primeira briga é contra a representação tradicional das Cortes espanholas, quando se entendia que os representantes só deveriam expressar aquilo que sua localidade oferecia como instrução e, portanto, deveriam silenciar sobre todos os outros temas. A moderna assembleia nacional, porém, supunha que seus deputados tinham direito à livre consciência e ao uso da razão e, por isso, estavam previamente autorizados a opinar sobre qualquer assunto.

28 Idem, OI set. I8II.

29 Semanário Patriótico, 28 fev. I8II. 
Além disso, as Cortes tinham que enfrentar a divisão das dezoito juntas soberanas. Em I8II, quatro meses após o início da reunião das Cortes, o Semanário Patriótico discutia com as juntas provinciais e pedia que se dissolvessem: "Uma de nossas necessidades mais urgentes é a de substituir as Juntas Provinciais por outros corpos que sirvam de enlace à representação nacional com as províncias". 30

Agregando-se ao problema das juntas provinciais espanholas, formadas e reconhecidas desde I808, havia a questão da América, onde o mesmo formato das juntas europeias se reproduzia, e no entanto não era reconhecido nas Cortes de Cádis. A ameaça da secessão foi sempre lembrada pelos deputados americanos e o Semanário reconhecia egoísmo e falta de amor à pátria nessa atitude, pois, para os seus autores, a nação era uma só: "Nessas pessoas, pois cada província cedeu à manifestação de seus desejos, e desde aquele momento os indivíduos foram nomeados representantes da nação e deixaram de se considerar enquanto castelhanos, aragoneses ou americanos". ${ }^{3 \mathrm{I}}$

Nesse aspecto, há outro ponto de discordância entre os editores de El Censor General e o Semanário Patriótico. O El Censor defendia as Cortes baseadas em estamentos:

Em contestação ao que V. disse, digo que as Cortes por braços ou estamentos é uma lei fundamental da Monarquia e tão antiga que se perde sua origem na sua antiguidade. Em Aragão assistiam a ela os quatro braços, em Castela os três do Povo, Nobreza e Clero. Aqui em Guipuzcoa, onde há foros muito livres, o Clero sempre concorre separadamente à eleição de seus deputados, e tem como o povo suas Juntas. [...] As leis de Castela assentadas sobre este antigo foro e costume sempre formaram as Cortes sobre esta base dos estamentos. [...] A Inglaterra deve sua liberdade a este método que adotou de nós, método pelo qual Robertson e outros estrangeiros elogiaram as instituições espanholas e acreditaram que nenhum povo se aproximou mais da sabedoria e liberdade romana que o nosso. Não nos esqueçamos, a história de nossas Cortes nos demonstra que esta é a lei fundamental delas e que não fomos livres senão até as Cortes de Toledo, na qual se eclipsou a liberdade pela supressão dos estamentos. ${ }^{32}$

Como podemos notar, esse momento peculiar da Espanha garantiu discussões que foram além do que convencionalmente se entende por guerra. Esses

30 Idem, 03 jan I8II.

3I Idem, O2 maio I8II.

32 El Censor General, 23 set. I8II. 
homens não trocaram ataques bélicos. Manifestaram-se no espaço público e utilizaram as palavras como munição. ${ }^{33}$ Essas palavras, porém, estavam em constante mutação e representavam posições políticas e ideológicas distintas.

\section{Iv. Os direitos individuais}

O Semanário Patriótico defende dois princípios básicos para a nova constituição política da Espanha: soberania nacional, conforme já foi explicado, associada à definição dos direitos individuais dos cidadãos espanhóis.

Assim, nessa concepção moderna, os súditos eram transformados em cidadãos. Nesse sentido, o Semanário Patriótico parece ser a encarnação dos princípios revolucionários da modernidade. A palavra ciudadano é usada trinta e duas vezes nos cinco jornais do mês de maio, por exemplo.

Cidadão carrega, no Semanário, uma carga ideológica que se transforma em ataque às estruturas do Antigo Regime, pois a transformação de todos em cidadãos teria o poder de extinguir os privilégios: "A Constituição sancionará os direitos do cidadão; fará a todos iguais diante da lei, e então olharão todos com desprezo estes resquícios de odiosa aristocracia”. ${ }^{34}$ A igualdade de todos é defendida numa frase emblemática: "Um espanhol só deve ajoelhar-se diante de Deus". ${ }^{35}$

Os direitos que devem ser repartidos igualmente entre todos os cidadãos são basicamente dois: a liberdade civil e a liberdade política.

Esses direitos deveriam ser controlados e garantidos pelo Estado: "Nem as leis destroem a liberdade nem os impostos ou contribuições aniquilam o direito de propriedade".${ }^{36}$ Adepto da ideia de um contrato social, em que cada um deve ceder uma parte da sua liberdade para recebê-la do Estado, o Semanário Patriótico estabelece também que o cidadão tem obrigações para com a Pátria, e durante as guerras napoleônicas ressaltava que "todos são cidadãos: todos devem ser soldados". 37

33 Como diz Fraçois-Xavier Guerra: "La palabray el término escrito, cesan muy pronto de ser sólo un arma, se convierten en la esencia misma del poder: lo que dice o quiere el pueblo o la nación. La palabra 'opinión', una de las palabras claves de la política moderna, invade rapidamente el discurso patriótico. La 'voz unánime de la nación' que rechaza al usurpadory proclama su fidelidad al rey cautivo, su 'acción unánime' para luchar contra el invasor, se convierten en la voluntad del pueblo, en la nación que actúa" (GUERRA, I992, p. 302).

34 Semanário Patriótico, IO mar. I8IO.

35 Idem, IO nov. I8IO.

36 Idem, O2 maio I8II.

37 Idem, I7 jan. I8II. 
A igualdade baseava-se na transformação de todos em indivíduos ligados à pátria, destruindo a ordem baseada em estamentos e que era denominada pelo próprio Semanário Patriótico como feudalismo. O ataque à antiga "ordem feudal" era feito claramente: "[os señorios são] os monumentos da ignorância daqueles tempos". ${ }^{38} \mathrm{De}$ acordo com os redatores do Semanário, haveria um conflito entre os interesses dos senhores e os direitos da nação: os primeiros deveriam, então, se submeter aos interesses gerais, ocupando um papel de proprietários, sem foros privilegiados.

$\mathrm{O}$ ataque não se dirige apenas aos nobres, mas atinge também o clero. Atuam nesse combate em muitas frentes: contestam o fato do clero não pegar em armas e não produzir, pois todos deveriam ser cidadãos-soldados; não acreditavam numa suposta solidariedade advinda dos princípios da Igreja católica e, por fim, criticavam duramente a cobrança de dízimos. De acordo com os princípios do Semanário, só as Cortes poderiam cobrar taxas ou impostos, e o pagamento de dízimos desviava parte dos recursos necessários para a manutenção do Estado: "o verdadeiro pobre do dia". ${ }^{39}$

El Censor General aborda toda a teoria sobre os direitos individuais como propagação da anarquia:

Que faz a anarquia para prevalecer? Confunde os direitos de propriedade, arma o pobre contra o rico, abole toda instituição de ordem, FAZ DE CADA HOMEM UM SOBERANO E DE GADA VONTADE UMA LEI. Portanto, é claro que uma Democracia subsistente só se encontrará quando sendo os homens iguais em deveres, respeite-se não obstante a desigualdade de fortunas, quando se faça inviolável a ordem social em que cada Cidadão ocupa um lugar, que não é comum aos outros, quando cada qual se tenha por súdito da comunidade para participar nela da Soberania: quando por fim não se confunda com o voto de todos o desejo ou paixão de poucos..$^{4 \circ}$

Defendem, assim, a ordem do Antigo Regime. Liberdade e soberania deveriam estar unidas em valores da tradição. Nessa forma de pensar, o súdito tem liberdade quando ocupa um lugar na sociedade. A segurança e a ordem são ideias chaves para compreender essa perspectiva. O receio da guerra apenas potencializa esses dois lemas que já são evidentes no discurso servil. Dessa forma, diferente do grupo de Quintana, só acreditam na união da sociedade 
espanhola mediante o respeito de uma ordem já existente. Reconheciam que essa ordem estava ameaçada pelas condições da guerra, mas lutavam pela sua manutenção para preservar a existência da Espanha.

\section{v. A nova ordem}

O Semanário Patriótico divulgava as ideias necessárias para a elaboração de uma Constituição guiada pelos dois princípios anteriormente expostos: soberania nacional e direitos do cidadão. Além disso, detalhava uma proposta para a nova administração, que deveria ser guiada pelos princípios de um Estado mais racional.

Primeiramente, a soberania, embora residisse unicamente na nação, deveria ser exercida na divisão de três poderes, evitando assim o despotismo. Estes seriam: o executivo (o rei e os ayuntamientos), legislativo (as Cortes) e judiciário (os tribunais). Nessa divisão de poderes, entretanto, o legislativo obtém maior importância como legítimo representante da nação e, por isso, teria a prerrogativa de designar e controlar as outras duas funções.

A nação deveria eleger o legislativo e grande parte do executivo, pois este também seria formado por ayuntamientos. O direito ao voto qualificava o cidadão e era estendido a boa parte da população: "Terão direito a votar em estas eleições todos os vecinos varões contribuintes que tenham 25 anos e não estejam encarcerados, nem sejam domésticos assalariados, e os eclesiásticos seculares; não serão excluídos nem os oficiais e aprendizes dos artesãos, nem os moços de trabalho e 'jornaleros', caso tenham os demais requisitos." $4 \mathrm{I}$

A eleição para o executivo seria feita através do voto nos municípios: escolhe-se os representantes dos ayuntamientos e, a partir de então, a eleição ocorre de maneira indireta. Os ayuntamientos municipales nomeiam os eleitores dos ayuntamientos de partido, que, por fim, nomeiam aqueles do ayuntamiento provincial, a instância máxima do executivo na província. Caberia também aos ayuntamientos recolher impostos e remetê-los ao poder central.

As propostas econômicas divulgadas pelo jornal e denominadas como Economia Política baseavam-se em um princípio bastante polêmico: "nacionalização" dos bens da Igreja. Para os redatores do Semanário, a dívida pública deveria ser paga com a disponibilização das terras ocupadas pelo clero. Dessa forma, pensavam que seria possível aumentar a produção agrícola e obter maior recolhimento de impostos. 
Além disso, o Estado deveria estabelecer a obrigatoriedade do pagamento de contribuições extraordinárias para a guerra, "que os desembolsos sigam a razão direta do que cada um tem a perder nessa guerra e do risco maior que se corre". ${ }^{42}$

Como foi visto, os editores de El Censor acreditavam que a Espanha já possuía uma Constituição muito antiga, baseada em duas defesas fundamentais: a religião católica e a monarquia. Propunham a regeneração das Cortes sempre organizada a partir dos estamentos. Dessa forma, conseguiriam representar verdadeiramente "los pueblos" de Espanha: "Como podem ser Cortes Gerais, como devem sê-lo e foram de fato as nossas antigas Cortes, não assistindo a elas esses braços principais, sendo representados como tais? Não há que temer que o seu poder obscureça os direitos do povo, porque existindo representantes de estas duas classes, ficam equilibrados esses poderes, de maneira que um não prevalece sobre o outro e ambos são o único freio que pode conter a tendência dos ministros reais para o despotismo." Essa proposta estamental se justificaria, inclusive, pela crise do erário. "Como poderá falar que forças teriam para defender a justiça do povo uns Deputados, que agora adulam ou contemporizam com os gastos supérfluos, para pedir a reforma dos gastos que estão agravando o erário com pensões que não mereciam gozar?" Qual proposta então seria feita? Para os editores de El Censor, "Só os homens ricos e independentes podem exercer bem o cargo de Diputación e apenas no método constitucional de estamentos pode-se encontrar essa classe de homens". ${ }^{43}$

\section{vi. A guerra interna}

A guerra contra os franceses terminou em I8I4 e deu lugar a uma verdadeira guerra interna que, para muito além das palavras, confrontou liberais e servis durante todo o século XIX na Espanha. O rei Fernando VII foi reconduzido ao trono em I8I4, fechou as Cortes reunidas em Cádis, anulou a Constituição finalizada em I8I2, perseguiu e puniu todos os liberais, sendo que o próprio redator principal do Semanário Patriótico, Manuel Quintana, foi preso. Nesse momento, de acordo com Pierre Vilar, venceu uma das Espanhas naturais e visíveis nas palavras dos servis. Em I820, os liberais reagiram, reiniciaram o movimento junteiro e fizeram com que Fernando VII jurasse a mesma Cons-

42 Idem, II abr. I8II.

43 El Censor General, 23 set. I8II. 
tituição que, a partir do mês de março, vigorou na Espanha até I823. Venceu, durante três anos, a Espanha liberal, que também tratou de afastar os antigos inimigos do poder.

A Constituição de Cádis foi adotada na Espanha ainda nos anos de I 836 e I837 e serviu como símbolo da defesa da nação espanhola até o final do século. No entanto, os liberais dividiram-se em inúmeros grupos e associaram-se para a elaboração de textos constitucionais que pudessem estabelecer um meio termo ou acordo com os diversos setores sociais da Espanha, que também passaram a incluir diversos tipos de "servis" (ou defensores do Antigo Regime). Todas essas tentativas posteriores à década de I820 registravam a necessidade de preservar a ordem contra revoluções e guerras. Mas expressavam também a impossibilidade de realizar uma total restauração do Antigo Regime e incorporavam a necessidade de estabelecer uma ordem inscrita em texto constitucional. Contudo, não havia acordo sobre os termos dessa nova Constituição. A Espanha teve sete constituições ao longo do século XIX e todas elas foram acompanhadas por enfrentamentos bélicos que os diversos acordos tentavam evitar: um pêndulo oscilou entre textos diversos e ora apontava para a soberania real e dinástica e ora seguia para o lado oposto e atendia às defesas da soberania nacional e popular. Os liberais "a moda gaditana”, defensores da Constituição nascida em Cádis de I8I2, enfrentaram os ultra "servis" e defensores de D. Carlos durante sete anos, entre I833 e I839, nas chamadas guerras carlistas. Mais à frente, enfrentaram a resistência da rainha e de seus apoiadores e viram a suspensão do texto concluído em I854. Entre I869 e I874, a disputa sobre as novas fórmulas constitucionais foi acompanhada por uma verdadeira abertura revolucionária e opôs os apoiadores (servis?) da monarquia à formação da primeira república que, ao final, foi extinta por um golpe regenerador e que também produziu uma Constituição. Tal como afirmaram os redatores do Semanário Patriótico e de El Censor General, entre I808 e I8I4, iniciou uma guerra que, apesar de manifesta em palavras, prometia ser mais longa do que a defesa nacional contra Napoleão Bonaparte. Na interpretação feita por Vilar, manifestavam-se duas Espanhas, paradoxas até o final do século e cujo enfrentamento antecede e anuncia a grande Guerra Civil do século XX.

\section{Referências bibliográficas}

ARTOLA, Miguel. En la España de Fernando VII. Madri: Espasa-Calpe, 2008. Las Cortes de Cádiz. Madri: Marcial Pons, 2003. 
AYMES, Jean-René. La guerra de independencia en España (1808-1814). Madri: Siglo XXI, I990.

BARROS, Mariana Monteiro de; Morel, Marco. Palavra, imagem e poder: o surgimento da imprensa no Brasil do século XIX. Rio de Janeiro: DP\&A, 2003.

BREÑA, Roberto. El primer liberalismo españoly los procesos de emancipación de América, 1808 -1824. México, D.F.: El Colegio de México, 2006.

FERNÁNDEZ SEBASTIÁN, Javier; FRANGISGO FUENTES, Juan. Diccionário político y social del siglo XIX español. Madri: Alianza Editorial, 2002. . Historia del periodismo español. Madri: Síntesis, I998.

GUERRA, François-Xavier. Modernidad e independencias: ensayos sobre las revoluciones hispánicas. México: Fondo de Cultura Económica; Fundación MAPFRE, I992. HABERMAS, Jürgen. Mudança estrutural da esfera pública: investigação quanto a uma categoria da sociedade burguesa. Rio de Janeiro: Tempo Brasileiro, 2003.

KOSELLECK, Reinhart. Futuro passado: contribuição à semântica dos tempos históricos. Rio de Janeiro: Ed. PUG-RJ/Contraponto, 2006.

RODRÍGUEZ, Jaime. The Independence of Spanish America. Cambridge: Cambridge University Press, 2006.

SÁIZ, María D.; SEOANE, María C. Historia del periodismo español. Madri: Alianza Editorial, I983.

SOLÍS, Ramón. El Cádiz de las Cortes. Madri: Silex Ediciones, I987.

SUÁREZ, Federico. Las Cortes de Cádiz. Madri: Rualp, I982.

VILAR, Pierre. Hildagos, amotinadosy guerrilleros. Barcelona: Crítica, I982.

Bruno Santos Sobrinho - Mestrando em História Social pela FFLGH - Universidade de São Paulo. bruno.sobrinho@gmail.com

Lucas Soares Chnaiderman - Graduando em História pela FFLGH - Universidade de São Paulo. lderman@uol.com.br 